\title{
Politik Hukum Administrasi Desa di Desa Dataran Kempas Kecamatan Tebing Tinggi Kabupaten Tanjung Jabung Barat
}

\author{
Netty, Irwandi, Nyimas Arfa \\ Fakultas Hukum, Universitas Jambi, Indonesia
}

\begin{abstract}
ABSTRAK
Pemerintah Daerah Provinsi, Kabupaten/Kota dapat melakukan penataan Desa. Penataan desa dilakukan berdasarkan hasil evaluasi tingkat perkembangan Pemerintahan Desa sesuai dengan ketentuan peraturan perundang-undangan. Penataan tersebut bertujuan: (a) mewujudkan efektivitas penyelenggaraan Pemerintahan Desa; (b)mempercepat peningkatan kesejahteraan masyarakat Desa; (c) mempercepat peningkatan kualitas pelayanan publik; (d) . meningkatkan kualitas tata kelola Pemerintahan Desa; dan (e) meningkatkan daya saing Desa. Dengan disahkan UU Nomor 6 Tahun 2014 Tentang Desa, diharapkan segala kepentingan dan kebutuhan masyarakat desa dapat diakomodir dengan lebih baik dan memberikan kesempatan yang lebih besar bagi desa untuk mengurus tata pemerintahannya. Metode penelitian yang dilakukan dengan jenis penelitian empiris. yang dapat dilakukan melalui penelitian lapangan atau turun langsung menemui sasaran penelitin guna mendapatkan data primer yaitu data yang diperoleh langsung dari pemerintah desa dan masyarakat yang merupakan sasaran dari penelitian ini. Dan penelitian normatif juga diperlukan sebagai teori dan data pendukung. melalui studi dokumen (penelitian kepustakaan dan penelitian lapangan) dan studi pustaka. Analisis data dalam penelitian ini dilakukan secara kualitatif lalu diuraikan secara deskritif. Hasil penelitian menunjukkan bahwa Politik hukum atau legal policy administrasi pemerintahan desa Dataran Kempas dari tahun ke tahun semakin menunjukkan kearah yang lebih baik terutama sekali dalam menetapkan garis-garis kebijaksanaan hukum atau aturan yang dianut oleh Pemerintah Desa dan BPD dalam penyelenggara pemerintahan desa beserta masyarakat desa sebagai komunitas yang mengatur dirinya sendiri. Dari Penelitian ini diharapkan sistem administrasi pemerintahan desa Dataran Kempas harus dapat menyesuaikan dengan perundang-undang yang berlaku. Memperkaya khasanah kajian Hukum Pemerintah desa khusus mengenai penataan administrasi desa dalam upaya pengembangan ilmu pengetahuan pemerintah desa. dan mencapai administrasi desa yang tertib dan memenuhi kehendak UU.
\end{abstract}

Kata Kunci: Politik hukum, admnistrasi, desa

\section{PENDAHULUAN}

\section{Latar Belakang Masalah}

Keberadaan desa sebagai satu kesatuan masyarakat hukum memberi pemahaman yang mendalam bahwa institusi desa bukan hanya sebagai entitas administratif belaka tetapi juga entitas hukum yang harus dihargai,diistimewakan, dilindungi dalam struktur pemerintahan di Indonesia. Pasal 18 ayat (2) UUD 1945 menyatakan: Negara mengakui dan menghormati kesatuan-kesatuan masyarakat hukum adat beserta hak-hak tradisionalnya sepanjang masih hidup dan sesuai dengan perkembangan masyarakat dan prinsip Negara Kesatuan Republik Indonesia, yang diatur dengan undang-undang. Berdasarkan pemahaman Pasal 18 B ayat (2) UUD 
1945, bahwa desa diartikan bukan saja sebagai kesatuan masyarakat hukum adat, tetapi juga sebagai hirarki pemerintahan yang terendah dalam Negara Kesatuan Republik Indonesia.

Sebagai pelaksana dari pernyataan di atas maka pemerintah mengeluarkan Undang-Undang Nomor 6 Tahun 2014 tentang Desa yang selanjutnya dilaksanakan oleh peraturan pemerintah Peraturan Pemerintah Nomor 72 Tahun 2005. . Pasal 2 ayat (1 dan 2) menentukan pembentukan desa dengan memperhatikan asal usul desa dan syarat yang sudah ditentukan. Hal ini dapat diartinya bahwa desa memiliki hak mengatur dan mengurus urusan rumah tangga sendiri sesuai kemampuanya. Sesuai amanat undang-undang pemerintahan daerah dalam mengatur kepentingan daerahnya peran dari aparat pemerintah daerah dan pemerintah desa merupakan dan sebagai ujung tombak dalam pelayanan bagi masyrakat yaitu pemerintah desa sebagaimana diatur dalam Pasal 202.

Kabupaten Tanjung Jabung Barat dengan ibu kota kabupaten Kuala Tungkal, yang terletak dengan batas wilayah antara 0o53' - 01o41' Lintang Selatan dan antara 103o23' - 104o21' Bujur Timur. Berdasarkan batas wilayah sesuai dengan pernyatakan sebelumnya secara geografisnya berbatasanan dengan : bagian Utara dengan Provinsi Riau, bagian Selatan dengan Kabupaten Batanghari Timur dengan Kabupaten Selat Berhala dan Kabupaten Tanjung Jabung Timur seerta bagian Barat berbatasan dengan Kabupaten Batanghari dan Kabupaten Tebo. Berdasarkan batas di atas maka secara formal memiliki luas wilayah keseluruhan adalah seluas 5.503,5 Km2 at $( \pm 26,68 \%$ ) dari keseluruhan luas Provinsi Jambi. Dengan pembagian 13 wilayah kecamatan, 114 wilayah desa dan 20 wilayah kelurahan.

Wilayah Kecamatan Tebing Tinggi terdapat dalam wilayah Tanjung Jabung Barat yang terdiri dari 10 desa. Desa yang terakhir terbentuk dari pemekaran adalah desa Dataran Kempas. Sebelum menjadi Desa definitif, Desa Dataran Kempas bernama Dusun Mekar Arum adalah bagian dari Desa Purwodadi. Tahun 2012 terjadi pemekaran Desa menjadi 3 Desa yaitu Desa Dataran Kempas, Desa Dataran Kempas dengan 3 dusun: (1) Dusun satu, terbagi atas 4 wilayah rukun tetangg yaitu wilayah rukun tetangga 01 (kosong satu) s/d wilayah rukun tetangga 04 (kosong empat), (2) Dusun dua, terdiri dari 5 (lima) wilayah Rukun tetanggayaitu wilayah rukun tetangga 05 (kosong lima) s/d wilayah rukun tetangga 09 (kosong sembilan) dan (3) Dusun 3 (tiga), terdiri dari empar wilayah rukun tetangga yaitu wilayah rukun tetangga 10 (sepuluh) s/d wilayah rukun tetangga 13 (tiga belas) dengan jarak ke ibu kota Provinsi Jambi $+150 \mathrm{~km}$. Dibawah pimpinan kepala desa yaitu Bapak Asbar Nofendra

Dengan keluarnya Undang-Undang pemerintahan desa yang baru, maka bertambah jelas tugas dan kewenangan yang diemban oleh pemerintah desa terkhusus dalam penataan administrasinya. Ini terbukti sebagaimana dinyatakan dalam Pasal 7 (tujuh) perundang-undangan pemerintahan terendah tentang tugas, kewenangan, tujuan pemerintah desa. Yaitu: 
1. Pemerintah, Pemerintah Daerah Provinsi, dan Pemerintah Daerah Kabupaten/Kota dapat melakukan penataan Desa.

2. Penataan sebagaimana dimaksud pada ayat (1) berdasarkan hasil evaluasi tingkat perkembangan Pemerintahan Desa sesuai dengan ketentuan peraturan perundang-undangan.

3. Penataan sebagaimana dimaksud pada ayat (1) bertujuan:

a. mewujudkan efektivitas penyelenggaraan Pemerintahan Desa;

b. mempercepat peningkatan kesejahteraan masyarakat Desa;

c. mempercepat peningkatan kualitas pelayanan publik;

d. meningkatkan kualitas tata kelola Pemerintahan Desa; dan

e. meningkatkan daya saing Desa.

4. Penataan sebagaimana dimaksud pada ayat (1) meliputi:

a. pembentukan;

b. penghapusan;

c. penggabungan;

d. perubahan status; dan

e. penetapan Desa.

Kenyataan ini merupakan suatu masalah yang bertentangan dengan ideologi negara dan perundang-undangan serta jiwa demokrasi negara Republik Indonesia Begitu juga dalam hal peningkatan asli desa, pada umumnya banyak sumber yang dapat menjadi Pendapatan Asli Desa tetapi belum tergali dan tidak digali oleh pemerintah desa.

Sesuai dengan apa yang dijabarkan dalam permasalahan tersebut di atas peneliti ingin mengkajinya lebih lanjut dengan judul penelitian : Politik Hukum Administrasi Desa di Desa Dataran Kempas Kecamatan Tebing Tinggi Kabupaten Tanjung Jabung Barat ".

\section{Rumusan Masalah}

Berdasarkan uraian yang telah dipaparkan dilatarbelakang di atas, maka peneliti merumuskan beberapa permasalahan yang akan menjadi kajian utama dalam penelitian yang akan dilakukan. Rumusan permasalahan tersebut adalah sebagai berikut:

1. Konsekuensi hukum yang bagaimana, yang cocok dan dapat diterapkan dalam pelaksanaan administrasi desa?

2. Bagaimana bentuk pengaturan dan mekanisme penataan administrasi desa yang sesuai dengan perundang-undangan

\section{TINJAUAN PUSTAKA}

\section{Tinjauan Umum tentang Desa}

Secara historis desa merupakan cikal bakal terbentuknya masyarakat politik dan pemerintahan di Indonesia jauh sebelum negara atau bangsa ini terbentuk. Struktur 
sosial sejenis desa, masyarakat adat dan lain sebagainya telah menjadi institusi sosial yang mempunyai posisi yang sangat penting. Kebanyakan desa di Indonesia baik yang berbentuk desa nelayan atau petani telah ada sejak ratusan atau bahkan ribuan tahun yang lalu. BN. Marbun mendefinisikan desa sebagai :

Satu daerah hukum yang ada sejak beberapa keturunan dan mepunyai ikatan kekeluargaan atau ikatan sosial yang hidup serta tinggal menetap di satu daerah tertentu dengan adat isitadat yang dijadikan landasan hukum dan mempunyai seorang pimpinan formil yaitu Kepala Desa. ${ }^{1}$

Menurut G. Kartasapoetra dkk yang menyatakan bahwa : Desa dapat berkembang karena para warganya mengutarakan asas-asas yang mempunyai nilai yang sangat universal yaitu :

1. Asas kegotongroyongan

2. Asas fungsi sosial atas milik dan manusia dalam masyarakat

3. Asas persetujuan sebagai dasar kekuasaan umum

4. Asas perwakilan dan permusyawaratan dalam sistem pemerintahanya

Hampir di seluruh tanah air tata kehidupan di desa-desa mempunyai persamaan, yaitu dengan asas-asas yang dimilikinya seperti di atas, para warga desa dapat menciptakan dan melangsungkan pemerintahannya dengan kemampuan para warga desanya itu sendiri. Dengan demikian dapat dikatakan bahwa setiap desa di tanah air telah memiliki sifat otonomi dalam arti mengatur atau mengurus rumah tangganya sendiri dengan kekuatan atau kemampuan sendiri. ${ }^{2}$

Desa di dalam perkembangan sejarah ketatanegaraan dan tata pemerintahan sampai sekarang merupakan suatu wilayah yang ditempati oleh sejumlah penduduk yang mempunyai organisasi pemerintahan terendah langsung di bawah camat, telah memiliki hak menyelenggarakan rumah tangganya. Dengan demikian perkembangan dan pengembangan otonomi selanjutnya baik ke samping ke atas dan/atau ke bawah, sebagaimana dimaksud dalam Undang Undang Nomor 32 Tahun 2004, tetap dimungkinkan sesuai dengan kondisi politik, ekonomi, sosial dan budaya serta pertahanan dan keamanan nasional.

Pemerintah Desa adalah Kepala Desa dan perangkatnya, hal ini sebagaimana yang dinyatakan dalam peraturan perundang-undangan yang mengatur tentang desa. Dalam pelaksanaan tugasnya, pemerintah desa dibantu oleh perangkat desa. Kepala desa sebagai orang pertama yang mengemban tugas dan kewajiban yang berat karena ia adalah penyelengaraan dan penanggung jawab utama dibidang pemerintahan, pembangunan, kemasyarakatan dan urusan pemerintahan umum termasuk pembinaan ketenteraman dan ketertiban. Di samping itu kepala desa juga mengembangkan tugas membangun mental masyarakat desa baik dalam bentuk menumbuhkan maupun mengembangkan semangat membangun yang dijiwai oleh

${ }^{1}$ Lihat BN. Marbun, Proses Pembangunan Desa Dalam Menyongsong Tahun 2000, Erlangga, Jakarta, 1980, hal. 19.

${ }^{2}$ Lihat G. Kartasapoetra dkk, Desa dan Daerah Dengan Tata Pemerintahannya, Bina Aksara, Jakarta, 1986, hal. 38 . 
asas usaha bersama dan kekeluargaan. Dengan beratnya tugas kepala desa itu, maka dalam menjalankan tugas dan kewajibannya, kepala desa sebagai penanggung jawab utama di bidang pembangunan dibantu oleh perangkat desa.

C.S.T. Kansil yang menyatakan bahwa : Kepala desa diharapkan aksebilitas dan kapabilitasnya dalam melaksanakan tugas pemerintahan dan pembangunan dan juga sebagai pembina masyarakat, maka ia harus seorang pancasilais yang mempunyai dedikasi yang penuh terhadap amanat penderitaan rakyat. Sehingga dengan demikian seorang kepala desa akan mampu untuk :

1. Melaksanakan tugas-tugas pemerintahan dan pembangunan di desa

2. Menampung dan menyelesaikan segala permasalahan yang timbul di desa

3. Membina hasil-hasil positif yang telah dicapai ke arah yang lebih baik. ${ }^{3}$

\section{Tinjauan Tentang Administrasi Pemerintahan Desa}

Pelaksanaan administrasi pemerintahan Desa ini menjadi kunci utama dalam mencapai pembangunan sebagai suatu organisasi pemerintahan terendah di bawah kecamatan yang memiliki otonomi asli, yang berhak mengatur dan mengurus rumah tangganya berdasarkan adat istiadat masyarakat setempat.Administrasi pemerintahan Desa merupakan kegiatan pencatatan data dan informasi mengenai aktivitas pemerintah Desa dalam kaitanya dengan tugas dan wewenang, yaitu menyelenggarakan urusan-urusan pemerintahan Desa. Dalam menyelenggarakan urusan-urusan Desa, pemerintah Desa berkewajiban melakukan berbagai pencatatan data dan informasi pada buku-buku register/model sesuai dengan urusan dan kepentingan Wasistiono (2006:8). Asas Penyelenggaraan Pemerintahan Desa, Dalam menyelenggarakan Pemerintahan Desa terdapat asas-asas yang harus diperhatikan, baik oleh Pemerintah maupun masyarakat Desa. Asas-asas penyelenggaraan Pemerintah Desa berdasarkan Pasal 24 Undang-Undang Nomor 6 Tahun 2014 Tentang Desa, antara lain sebagai berikut: Asas Kepastian Hukum; Asas Tertib Penyelenggaraan Pemerintahan; Asas Tertib Kepentingan Umum; Asas Keterbukaan; Asas Proporsionalitas; Asas Profesionalitas; Asas Akuntabilitas; Asas Efektivitas dan Efisiensi; Asas Kearifan Lokal; Asas Keberagaman; Asas Partisipatif;

\section{METODE PENELITIAN}

Penelitian ini dilaksanakan di salah satu desa yang memiliki permasalahan administrasi pemerintahan desa, hal ini menurut pengamatan baik secara formal maupun secara norma desa ini baru beberapa tahun terbentuk (lebih kurang 7 tahun) dari pemekaran desa. Desa yang baru terbentuk karena pemekaran ini dinamakan dengan Desa Dataran Kempas yang terletak dalam wilayah Kecamatan Tebing Tinggi Kabupaten Tanjung Jabung Barat Provinsi Jambi. Dengan jenis penelitian empiris atau Penelitian lapangan aartinya turun langsung menemui

${ }^{3}$ Lihat CST. Kansil, Desa Kita Dalam Peraturan Tata Pemerintahan Desa, Ghalia Indonesia, Jakarta, 1988, hal. 32 . 
sasaran penelitin guna mendapatkan idata primer yaitu data yang diperoleh langsung dari pemerintah desa, masyarakat atau sasaran penelitian sebagai sumber utamanya. Perolehan data primer dapat melalui wawancara langsung ${ }^{4}$ Di samping penelitian empiris, penelitian ini juga bersifat normatif karena diperlukan sebagai teori dan data pendukung. Data dianalisi secara kualitatif, yang akan dipaparkan dalam bentuk uraian atau pernyataan. Kemudian dari analisisini akan ditarik suatu kesimpulan dengan mengguna kan metode induktif.

\section{HASIL DAN PEMBAHASAN}

\section{Konsekuensi hukum/pengaturan pelaksanaan administrasi desa Dataran Kempas}

Politik hukum atau legal policy pemerintahan desa dari tahun ke tahun semakin menunjukkan kearah pembentukan civil society atau meminjam istilah Nurcholis Madjid "masyarakat madani".Politik hukum pemerintahan desa yang dimaksud disini adalah arah kebijakan hukum pemerintahan desa secara nasional, yakni garis-garis besar kebijaksanaan hukum yang dianut oleh penyelenggara negara dalam usaha danupaya memelihara,memperuntukkan, mengambil manfaat, mengatur dan mengurus pemerintahan desa beserta masyarakat desa sebagai komunitas yang mengatur dirinya sendiri. Hal ini telah nampak dengan dikeluarkannya Peraturan Pemerintah Nomor 72 Tahun 2005 tentang desa sebagai ganti dari undang-undang nomor 5 tahun 1979 tentang pemerintahan desa. Dalam PP ini menurut Prof Ateng dan Suprin ${ }^{17}$ telah mempunyai pemikiran tentang pengaturan mengenai desa yaitu:

1. Keanekaragaman yang memiliki makna bahwa istilah desa dapat disesuaikan dengan asal-usul dan kondisi social budaya masyarakat setempat. Hal ini berarti pola penyelenggaraan pemerintahan serta pelaksanaan pembangunan di desa harus menghormati sistem nilai yang berlaku pada masyarakat setempat,tetapi juga harus tetap mengindahkan sistem nilai bersama dalam kehidupan berbangsa dan bernegara.

2. Partisipasi, memiliki makan bahwa penyelenggaraan pemerintahan dan pembangunan desa harus mampu mewujudkan peran aktif masyarakat agar masyarakat senantiasa memiliki danturut serta bertanggungjawab terhadap perkembangan kehidupan bersama sesame warga desa

3. Otonomi asli, memiliki makna bahwa kewenangan pemerintah desa dalam mengatur dan mengurus masyarakat setempat didsarkan pada hak asal ususl dan nilai-nilai social budaya yang terdapat pada masyarakat setempat ,tetapiharus diselenggarakandalam prespektif administrasi pemerintahan negara yang selalu mengikuti perkembangan zaman.

4. Demokratisasi, memiliki makna bahwa penyelenggaraan pemerintahan dan pelaksanan pembangunan di desa harus mengakomodasi aspirasi masyarakat 
yang diartikulasikan dan diagregarsikan melalui BPD dan lembaga kemasyarakatan sebagai mitra pemerintahan desa.

5. Pemberdayaanmasyarakat, memiliki makna bahwa penyelenggaraan pemerintahan dan pelaksanaan pembangunan di desa ditujukan untuk meningkatkan taraf hidup dan kesejahteraan masyarakat melalui penetapan kebijakan, progam dan kegiatan yang sesuai dengan esensi masalah dan prioritas kebutuhan masyarakat.

Secara umum, Ateng Syarifudin berpendapat bahwa politik hukum pemerintahan desa yang paling mutakhr adalah sebagai berikut:

1. Desa atau yang disebut dengan nama lain adalah suatu keatuan masyarakat hukum yang mempunayi susunan asli berdasarkan hak asal-usul yang bersifat istimewa, sebagaimana dimaksud dalam Pasal 18 UUD 1945. Landasan pemikiran dalam pengaturan mengenai pemerintahan desa adalah keanekaragaman, partisipasi, otonomi asli, demokrasi dan pemberdayaan masyarakat;

2. Penyelenggaraan pemerintahan desa merupakan sub sistem dari sistem penyelenggaraan pemerintahan sehingga desa memiliki kewenangan untuk mengatur dan mgurus kepentingan masyarakatnya. Kepala desa bertanggungjawab pada badan permusyawaratan desa dan menyampaikan laporan pelaksanaan tugas tersebut kepada bupati/walikota.

3. Desa dapat melakukan perbuatan hukum, baik hukum public maupun hukum perdata, memiliki kekayaan, harta benda, dan bangunan serta dapat dituntut dan menuntut di muka pengadilan. Untuk itu kepala desa dengan persetujuan BPD mempunyai wewenang untuk melakukan perbuatan hukum dan mengadakan perjanjian yang saling menguntungkan.

4. Sebagai perwujudan demokrasi, di desa dibentuk BPD atau sebutan lain yang sesuai dengan budaya yang berkembang di desa yang bersangkutan, yang berfungsi sebagai lembaga legislasi dan pengawasan dalam hal pelaksanaan peraturan desa, anggran pendapatan dan belanja desa, peraturan kepala desa dan keputusan desa.

5. Di desa dibentuk lembaga masyarakat desa lainnya sesuai dengan kebutuhan desa. Lembaga dimaksud merupakan mitra pemerintah desa dalam rangka pemeberdayaan masyarakat desa.

6. Desa memiliki sumebr pembiayaan berupa pendapatan desa, bantuan pemerintah dan pemerintah daerah, pendapatn lain-lain yang sah, sumbangan pihak ketiga dan pinjaman desa.

7. Berdasarkan hak asal-usul desa yang bersangkutan, kepala desa mempunyai wewenang untuk mendamaikan perkara / sengketa dari para warganya.

8. Dalam upaya meningkatkan dan mempercepat pelayanan kepada masyarakat yang bercirikan perkotaan dibentuk kelurahan yang berada di dalam daerah kabuoaten/kota. 


\section{Bentuk Pengaturan dan Mekanisme penataan administrasi desa Dataran Kempas}

Administrasi pemerintahan Desa merupakan kegiatan pencatatan data dan informasi mengenai aktivitas Pemerintah Desa dalam kaitanya dengan tugas dan wewenang, yaitu menyelenggarakan urusan-urusan pemerintahan Desa. Administrasi pemerintahan Desa yang merupakan subsistem dari sistem penyelenggaraan pemerintahan menjadikan Desa sebagai tumpuan dan ujung tombak dalam penyelenggaraan Pemerintahan dan pelaksanaan pembangunan sekaligus sumber data dan informasi dalam penentuan berbagai kebijaksanaan pemerintahan secara nasional. Hal ini harus didukung oleh Pelayanan masyarakat mengenai administrai yaitu pelayanan yang menghasilkan berbagai bentuk dokumen resmi seperti pelayanan registrasi kependudukan. Pelayanan administrasi dimasyarakat seperti pelayanan pembuatan kartu domisili, surat pengantar pembuatan e-KTP, KK dan lain-lain. Aspek-aspek kecepatan, ketepatan, kemudahan, dan keadilan menjadi alat untuk mengukur pelayanan kepada masyarakat. Terutama dalam bidang administrasi sebagai berikut:

\section{Administrasi Umum}

Pelaksanaan administrasi umum Pemerintah Desa Dataran Kempas Kecamatan Tebing Tinggi Kabupaten Tanjung Jabung Barat ini menjadi kunci utama dalam mencapai pembangunan di Desa Dataran Kempas, sebagai suatu organisasi pemerintahan terendah di bawah kecamatan yang memiliki otonomi asli, yang berhak mengatur keadaan administrasi umum mereka sendiri. Oleh karenanya pelaksanaan administrasi umum pemerintahan di Desa Dataran Kempas Kecamatan Tebing Tinggi Kabupaten Tanjung Jabung Barat menjadi salah satu prioritas Aparat pemerintah di Desa Dataran Kempas Kecamatan Tebing Tinggi Kabupaten Tanjung Jabung Barat Adapun pelaksanaan administrasi umum di Desa Dataran Kempas Kecamatan Tebing Tinggi Kabupaten Tanjung Jabung Barat dalam hal ini mengenai pengelolaan buku data peraturan Desa dan buku administrasi desa lainnya. dari hasil penelitian dapat disimpulkan bahwa Aparat di Desa Dataran Kempas Kecamatan Tebing Tinggi Kabupaten Tanjung Jabung Barat kurang mampu mengelolo buku data peraturan Desa dan buku administrasi lainnya. Aparat pemerintah Desa Dataran Kempas Kecamatan Tebing Tinggi Kabupaten Tanjung Jabung Barat tidak selalu konsisten melakukan pekerjaanya dan tidak sesuai dengan tugas pokok dan fungsinya disebabkan ada beberapa alasan yaitu keterbatasan Aparat Desa dalam mngelola komputer serta upah/gaji tidak sesuai dengan apa yang diharapkan untuk diterimanya.

\section{Administrasi Penduduk}

Pelaksanaan administrasi penduduk yang dimaksud dalam penelitian ini adalah kegiatan pencatatan data dan informasi mengenai penduduk dan mutasi penduduk pada buku administrasi penduduk. Berdasarkan hasil penelitian Aparat pemerintah 
Desa Dataran Kempas Kecamatan Tebing Tinggi Kabupaten Tanjung Jabung Barat senantiasa melakukan segenap pencatatan data dan informasi tentang keadaan penduduk sehingga Aparat pemerintah Desa Dataran Kempas Kecamatan Tebing Tinggi Kabupaten Tanjung Jabung Barat dapat mengetahui dengan jelas mengenai keadaan jumlah penduduk dan memudahkan para Aparat Desa Diolo dalam merekapitulasi jumlah penduduk di Desa Dataran Kempas Kecamatan Tebing Tinggi Kabupaten Tanjung Jabung Barat. Adapun pelaksanaan administrasi kependudukan di Desa Dataran Kempas Kecamatan Tebing Tinggi Kabupaten Tanjung Jabung Barat dalam hal ini tentang pengelolaan buku data penduduk dari hasil penelitian bahwa administrasi kependudukan di Desa Dataran Kempas Kecamatan Tebing Tinggi Kabupaten Tanjung Jabung Barat telah ditata dengan baik dalam artian pelaksanaan administrasi kependudukan di Desa Dataran Kempas Kecamatan Tebing Tinggi Kabupaten Tanjung Jabung Barat telah berjalan efektif sehingga segenap informasi tentang keadaan jumlah penduduk Desa Dataran Kempas Kecamatan Tebing Tinggi Kabupaten Tanjung Jabung Barat dapat diketahui dengan baik.

\section{Administrasi keuangan}

Pelaksanaan administrasi keuangan yang dimaksud dalam penelitian ini adalah kegiatan pencatatan data dan informasi mengenai pengelolaan keuangan Desa pada buku administrasi keuangan. Berdasarkan hasil penelitian, Aparat pemerintah Desa Dataran Kempas Kecamatan Tebing Tinggi Kabupaten Tanjung Jabung Barat senantiasa melakukan segenap pencatatan data dan informasi tentang pengelolaan anggaran keuangan di Desa Diolo dalam buku administrasi keuangan Desa sehingga masyarakat Desa Dataran Kempas Kecamatan Tebing Tinggi Kabupaten Tanjung Jabung Barat dapat mengetahui dengan jelas mengenai pengelolaan keuangan yang ada di Desa Dataran Kempas baik keuangan yang bersumber dari bantuan Pemerintah maupun yang berasal dari swadaya masyarakat. Melalui pelaksanaan administrasi keuangan di Desa Dataran Kempas Kecamatan Tebing Tinggi Kabupaten Tanjung Jabung Barat yang telah berjalan dengan baik, masyarakat akan mengetahui tentang keadaan keuangan Desa dan kemana saja pospos anggaran tersebut disalurkan. Melalui pengadministrasian keuangan di Desa Dataran Kempas Kecamatan Tebing Tinggi Kabupaten Tanjung Jabung Barat Aparat Desa dan masyarakat dapat mengetahui dan merencanakan besar anggaran yang akan dikeluarkan dan dibutuhkan dalam pelaksanaan pembangunan di Desa Dataran Kempas Kecamatan Tebing Tinggi Kabupaten Tanjung Jabung Barat. Adapun pelaksanaan administrasi keuangan di Desa Dataran Kempas Kecamatan Tebing Tinggi Kabupaten Tanjung Jabung Barat dalam hal ini tentang pengelolaan anggaran pendapatan Desa, dari penjelasan hasil penelitian disimpulkan bahwa pengelolaan anggaran pendapatan di Desa Dataran Kempas Kecamatan Tebing Tinggi Kabupaten Tanjung Jabung Barat Aparat pemerintah telah mengelola dengan baik dalam artian pengelolaan keuangan di Desa Dataran Kempas Kecamatan 
Tebing Tinggi Kabupaten Tanjung Jabung Barat telah berjalan efektif sehingga segenap informasi tentang pengelolaan anggaran pendapatan Desa dicatat dalam buku administrasi keuangan Desa dan masyarakat dapat mengetahui penggunaan anggaran di Desa Dataran Kempas Kecamatan Tebing Tinggi Kabupaten Tanjung Jabung Barat

\section{Administrasi Pembangunan}

Melalui pelaksanaan administrasi pembangunan di Desa Dataran Kempas Kecamatan Tebing Tinggi Kabupaten Tanjung Jabung Barat yang telah berjalan dengan baik, masyarakat akan mengetahui tentang rencana pembangunan Desa yang akan dilaksanakan. Adapun pelaksanaan administrasi pembangunan di Desa Dataran Kempas Kecamatan Tebing Tinggi Kabupaten Tanjung Jabung Barat dalam hal ini mengenai rencana pembangunan Desa, dari hasil penelitian bahwa perencanaan adalah proses penting dalam pelaksanaan pembangunan dan pelibatan masyarakat merupakan upaya untuk mendekatkan kebutuhan masyarakat dalam kerangka pilihan keputusan dalam perencanaan, peenyusunan rencana kegiatan pembangunan di Desa Dataran Kempas Kecamatan Tebing Tinggi Kabupaten Tanjung Jabung Barat telah dilakukan dengan baik sehingga rencana pembangunan Desa Dataran Kempas Kecamatan Tebing Tinggi Kabupaten Tanjung Jabung Barat dapat terlaksana dengan baik.

Pelaksanaan administrasi di atas berdasarkan hasil penelitian di desa Dataran Kempas dalam hal :

1. Kecepatan, Aparat yang memberikan layanan administrasi kependudukan di Desa Dataran Kempas harus mempunyai kesiapan merealisasikan kebutuhan masyarakat, tidak ada alas an menunda atau memperlambat pemberian layanan, kapanpun masyarakat membutuhkan layanan administrasi kesehatan pada saat itu pula Aparat telah stand by untuk melayani. Adapun pelayanan masyarakat yang menyangkut dengan kecepatan di Desa Dataran Kempas dari penjelasan hasil penelitian bahwa kecepatan proses layanan administrasi yang diberikan kepada masyarakat oleh Aparat pemerintah di Desa Dataran Kempas adalah baik, karena Aparat pemerintahdi Desa Dataran Kempas dengan cepat dan tepat melayani segenap kebutuhan masyarakat dan hal ini memungkinkan pelayanan yang diberikan Aparat pemerintah Desa Dataran Kempas terlaksana dengan baik.

2. Ketepatan, Ketepatan dalam pelayanan berarti layanan administrasi yang diberikan oleh Aparat kepada masyarakat harus persis, tidak kurang dan tidak lebih, sesuai dengan janji. Hal ini dapat dilihat melalui produk dan proses layanan. Adapun pelayanan masyarakat yang menyangkut dengan ketepatan di Desa Dataran Kempas Hasil penelitian bahwa ketetapan proses layanan yang diberikan kepada masyarakat oleh Aparat Desa Dataran Kempas cukup baik, 
hal ini karena Aparat pemerintah Desa memberikan segenap pelayanan seperti pelayanan administrasi pelayanan kesehatan serta pelayanan lainya sesuai dengan kebutuhan masyarakat.

3. Kemudahan, Penyediaan layanan yang mudah dan biaya yang diminta sesuai tarif dan tidak ada biaya tambahan merupakan salah satu bentuk pelayanan yang harus mendapat priorotas utama. Dari hasil penelitian wawancara disimpulkan bahwa kemudahan layanan administrasi yang diberikan kepada masyarakat oleh Aparat pemerintah Desa Dataran Kempas berjalan dengan baik, karena Aparat pemerintah Desa selalu siap melayani kebutuhan masyarakat dan dalam pemberian layanan tersebut biaya/tariff yang diminta sesuai dengan kemampuan masyarakat dan tidak membutuhkan waktu yang lama.

4. Keadilan, Rasa keadilan yang mudah dalam kehidupan masyarakat sehari-hari sejauh mana layanan administrasi atau pelayanan lainya diterima oleh masyarakat secara menyeluruh tanpa memandang asal-usul, strata sosial dan ekonomi masyarakat yang dilayaninya. mendapatkan pelayanan terpenuhi dan diutamakan. Dari hasil penelitian bahwa keadilan layanan administrasi ataupun layanan lainya yang diberikan kepada masyarakat Desa Dataran Kempas belum terlaksana dengan baik, Aparat pemerintahan Desa masih membeda-bedakan antara masyarakat yang mempunyai status sosial dengan masyarakat biasa sehingga, dalam pelayanan masih terdapat unsur diskriminatif atau tidak meratanya dalam pemberian layanan.

\section{Kesimpulan}

\section{KESIMPULAN DAN SARAN}

Pemerintah Desa Dataran Kempas Kecamatan Tebing Tinggi Kabupaten Tanjung Jabung Barat, telah melakukan arah kebijakan hukum pemerintahan desa secara nasional, yakni garis-garis besar kebijaksanaan hukum yang dianut oleh penyelenggara negara dalam usaha dan upaya memelihara,memperuntukkan , mengambil manfaat, mengatur dan mengurus pemerintahan desa beserta masyarakat desa sebagai komunitas yang mengatur dirinya sendiri.Hal ini terbukti dengan pelaksanaan beberapa perintah perundang-undangan tentang penataan administrasi desa. Tetapi dalam pelaksanaannya masih belum maksimal. Hal ini terlihat dalam pelayanan terhadap masyarakat yang belum terpenuhi secara adil

\section{Saran}

Untuk mengoptimalkan pelaksanaan administrasi desa, di Desa Dataran Kempas harus dengan arah yang jelas. Artinya pelaksanaannya harus sesuai dengan kebijakan Yang ada dan dengan mekanisme serta sistem yang baku dan dapat dipertanggungjawabkan sesuai aturan.

\section{DAFTAR PUSTAKA}




\section{Buku}

Ateng Syarifuddin, 2010, Republik Desa, Alumni:Bandung

BagirManan,1993,Perjalanan historis Pasal 18 UUD 1945, Uniska Karawang

Didik Sukaryono, 2010, Pembaharuan Hukum Pemerintah Desa, Setara

Press:Malang

HAW.Widjaja,2012, Otonomi Desa (Merupakan Otonom yang Asli, Bulat

Utuh),Rajawali Press:Jakarta

Imam Syaukani, dan A. Ahsin Thohari, 2006, Dasar-dasar Politik Hukum, Raja

Grafindo Persada: Jakarta

Mahfud M.D, 1998. Politik Hukum di Indonesia, LP3ES:Jakarta

Sadjijiono, 2008, Memahami Beberapa Bab Pokok Hukum Administrasi, Pressindo: Yogyakarta

Marzuki, Peter Mahmud. Penelitian Hukum. Kencana, Jakarta, 2009.

Nasution, Bahder Johan. Metode Penelitian Ilmu Hukum. Mandar Maju, Bandung, 2008.

Soerjono, Soekanto. Sosiologi Suatu Pengantar. Rajawali Pers, Jakarta, 2009.

Suratman dan Phillips Dillah, Metode Penelitian Hukum, Cetakan ke-2, Alfabeta, Bandung, 2014.

Wardoyo. Kamus Besar Bahasa Indonesia. Balai Pustaka, Jakarta, 1980.

Widjaja, HAW. Otonomi Desa. PT Raja Grafindo Persada, Jakarta, 2003.

Widiyanto, Ardhi. "UU Desa: Membangun Masyarakat Sejahtera”. Majalah Pendopo, Edisi IX Tahun 2014.

\section{Peraturan Perundang-undangan}

Republik Indonesia. Undang-Undang Nomor 6 Tahun 2014 tentang Desa. . Peraturan Menteri Dalam Negeri Nomor 113 tahun 2014 tentang Pengelolaan Keuangan Desa.

Peraturan Menteri Dalam Negeri No 32 Tahun 2006, Tentang Pedoman Administrasi Desa.

- Peraturan Menteri Nomor 4 Tahun 2017 tentang Perubahan atas Peraturan Menteri Desa, Pembangunan Daerah Tertinggal dan Transmigrasi Nomor 22 Tahun 2016 tentang Penetapan Prioritas Penggunaan Dana Desa Tahun 2017. 